\title{
Determination of Chromites Prospects Using Multifractal Models and Zonality Index in the Parang 1:100000 Sheet, Iran
}

\author{
Amir Navidi ${ }^{1}$, Mansour Ziaii ${ }^{1}$, Peyman Afzal ${ }^{2,3}$, Amir Bijan Yasrebi ${ }^{3, *}$, Andy Wetherelt ${ }^{3}$, Patrick Foster $^{3}$ \\ ${ }^{1}$ Faculty of Mining, Petroleum and Geophysics, Shahrood University of Technology, Shahroud, Iran \\ ${ }^{2}$ Department of Mining Engineering, South Tehran Branch, Islamic Azad University, Tehran, Iran \\ ${ }^{3}$ Camborne School of Mines, University of Exeter, Penryn, UK \\ *Corresponding Author: aby203@exeter.ac.uk
}

Copyright (C) 2014 Horizon Research Publishing All rights reserved.

\begin{abstract}
Recognition of geochemical halos is one of the most important tools for exploration of undiscovered ore deposits. The aim of this study is prospecting for chromite deposits located in the Parang 1:100000 sheet, SE Iran, based on stream sediment data. To do this, geochemical zonality index and Concentration-Area (C-A) fractal modeling were used for chromite prospects determination. Multiplied values of $\mathrm{Cr}, \mathrm{Co}$ and $\mathrm{Ni}$ as the zonality index for prospecting of chromite deposits and various geochemical anomalies were distinguished based on the C-A fractal model log-log plots which indicate four geochemical populations for $\mathrm{Cr}, \mathrm{Co}, \mathrm{Ni}$ and zonality index in the area with low intensive anomalies thresholds of $0.141 \mathrm{ppm}, 17 \mathrm{ppm}, 77 \mathrm{ppm}$ and 7,943,282 $\mathrm{ppm}^{3}$ respectively. Results obtained by the C-A modeling show that the high intensive anomalies for multiplication of Cr.Co.Ni and $\mathrm{Cr}$ are located in the western and central of the studied area. Finally, the result obtained by zonality index and the $\mathrm{C}$-A fractal modeling and $\mathrm{Cr}$ anomalies was compared by log-ratio matrix which illustrates that the western and central parts of the area are associated with chromite prospects having a good correlation with the geological model in the Parang 1:100,0000 sheet.
\end{abstract}

Keywords C-A Fractal Model, Zonality Index, Chromite Ore Deposit

\section{Introduction}

Primary halos of mineral deposits are formed by interactions between host rocks, ore fluids and ore elements enrichment which occur within alteration zones [1-8].

Different geochemical methods presented in regard with geochemical features of primary halos. Stream sediment data is a common geochemical technique for identification of mineral deposits in a regional scale [9]. Beus and Grigorian [10] proposed a model for detection of prospects using the geochemical zonality index for different ore deposits in the various landscapes at the regional scale. Metallometric methods have been utilized for delineation of geochemical anomalies associated with mineralized area [11-13] which do not have enough efficiency for exploration in the following situations: (1) presence of significant heavy metal contamination of stream sediments due to mining activities ; (2) low relief areas of hydromorphic dispersion predominates over mechanical dispersion of metals from ore deposits [14]. Fractal/multifractal models established by Mandelbrot [15] have widely applied for delineation of geochemical anomalies from background. Fractal theory has been used to prospect ore deposits since 1980s [16-25].Cheng [19] proposed the Concentration-Area (C-A) fractal model for definition of different geochemical anomalies and background. In this paper, the C-A fractal modeling and zonality index were applied for prospecting of chromite deposits in the Prang 1:100000 sheet, SE Iran.

\section{Geological Setting}

The studied area was located in South Khorasan province and near to Birjand city in the ophiolite SE Iran belt which has more than 20 podiform chromite ore deposits [26] (Fig 1).The main formation and rocks in the studied area relate to Mesozoic ophiolites complex and Cretaceous sediments. The ophiolitic zone has all member of ophiolite sequences including; Listinvite, Radiolarite, Plagiogranite, Basic tuff, Diabase, Gabbro, Serpentinite and Ultramaphic rock mainly lherzolite and harzburgite.

The main Iranian ophiolites occur in Mesozoic and Paleozoic rocks (Fig1 a). The most of Mesozoic ophiolites are located among the Iranian plate in the north and the Arabian plate in the south, and have been grouped by Lensch and Davoudzadeh [27] and Stöcklin [28] into an outer and inner sub-belt. The inner sub-belt (Central Iran type) is located around the Central Iranian micro-continent and 
includes the Sabzevar, Nain-Baft, Esfandagheh, Makran and Birjand ophiolites [29-39].The ophiolitic complex of this zone is hosted by serpentinite andperidotites. Peridotitic host rocks consist of harzburgite and lherzolite in the ophiolites and wehrlite in the overlying cumulate sequence. Some chromite bodies occur in dunite layers in the cumulate contact [40].

\section{Methodology}

The studied area was gridded based on the distances between sample locations, and also the cell sizes were selected $200 \times 200 \mathrm{~m}^{2}$. The C-A log-log plots were generated for zonality index and different geochemical populations were distinguished. Furthermore, chromite prospects were generated based on results obtained by the C-A fractal model. Finally, the prospects were correlated with geological particulars with respect to log-ratio matrix proposed by Carranza.

a)

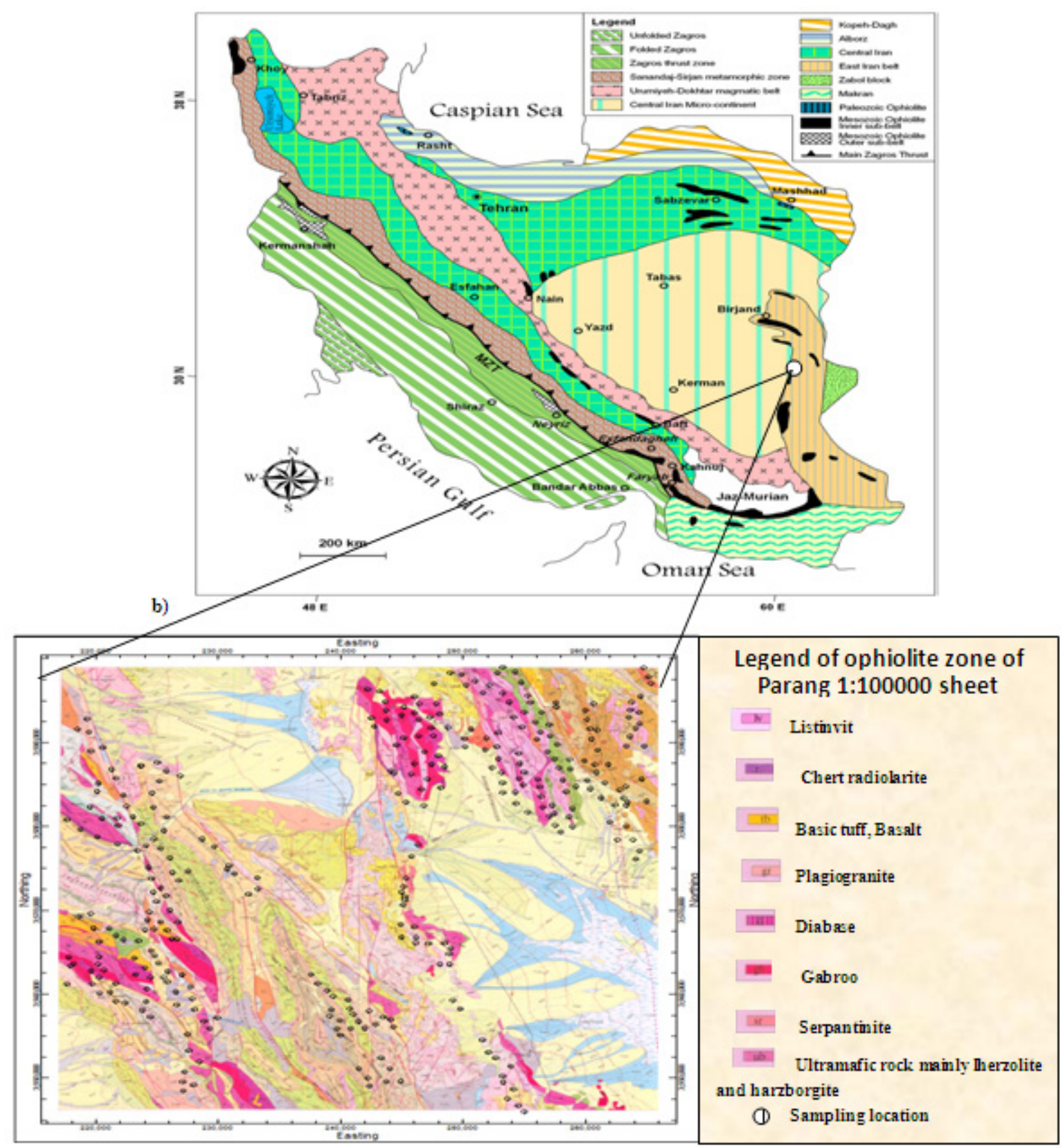

Figure 1. a) Schematic map of distribution of chromites sequences in Iran b) geological map of Parang 1:100000 sheet 


\section{Concentration-Area Fractal Model}

Cheng et al. [19] proposed the concentration-area (C-A) fractal model for delineation of geochemical anomalies and background due to the distribution of elemental concentrations. This model has the general form as follow:

A $(\rho \leq v) \infty \rho-a 1 ; A(\rho \geq v) \infty \rho-a 2(1)$

Where A $(\rho \leq v)$ and A $(\rho \geq v)$ represent areas (A) with concentration values smaller or greater than contour value $\rho$, also $v$ represents the threshold ; a1 and a2 are characteristic exponents which denote fractal dimension. Threshold values in this model indicate boundaries between different geochemical populations.

\section{Application of Multifractal Modeling, Factor Analyzes and Zonality Index}

Multifractal model was applied for exploration of chromite prospecting in the Parang1:100000 sheet, SE Iran. The collected geochemical data consists of 320 stream sediment samples (Fig 1b) were analyzed by BRGM (French Geological Survey) for 33 elements utilizing ICP-MAS.
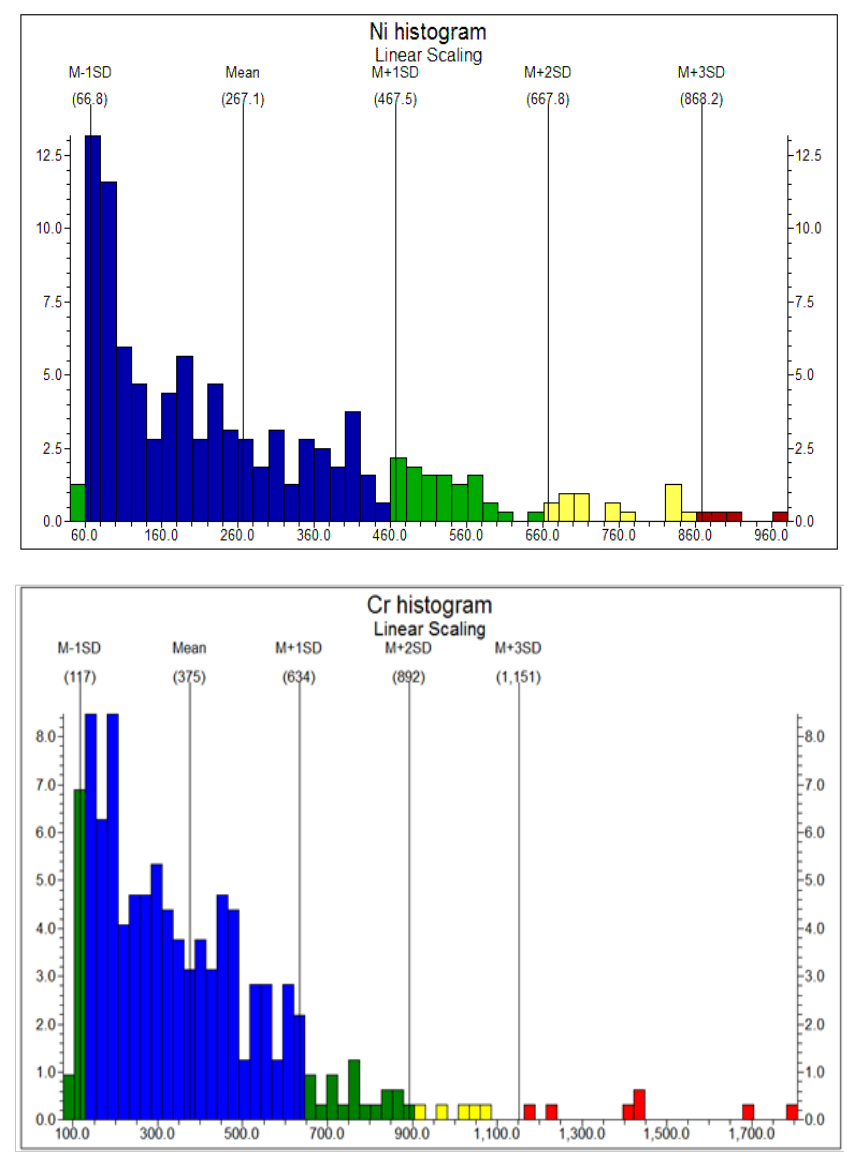

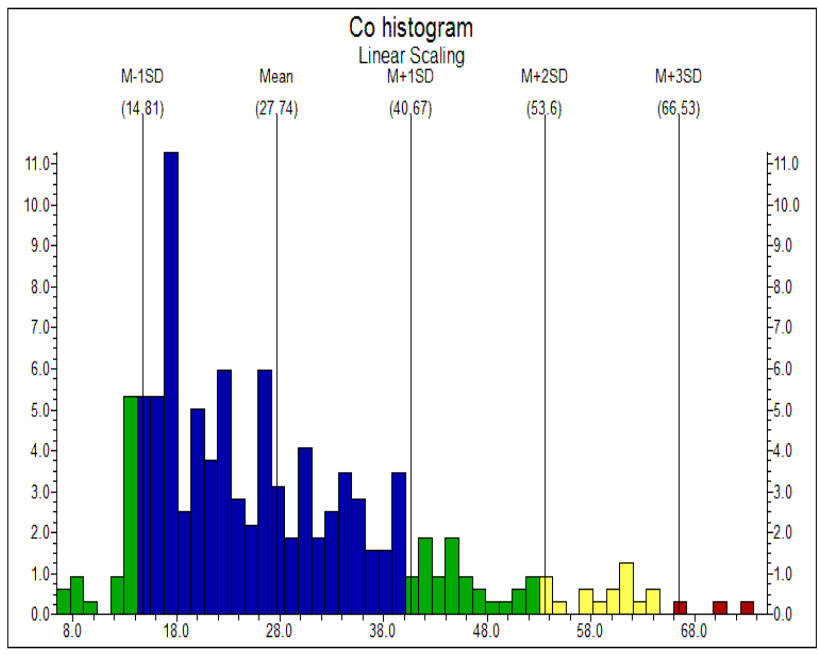

Figure 2. Histogram plots of $\mathrm{Cr}, \mathrm{Co}$ and $\mathrm{Ni}$

This research investigated $\mathrm{Cr}$, Co, Ni elements and an exploration indicator for chromite deposits prospecting which was proposed based on the multiplied values of these elements as the zonality index. However, the association of $\mathrm{Co}, \mathrm{Ni}$ and $\mathrm{Cr}$ values could be a suitable indicator for prospecting of chromite deposits as well as statistical parameters of the data (Fig 2 and Table 1). Histograms of Cr, $\mathrm{Co}$ and Ni show multimodal distribution, as depicted in Fig. 3. The geochemical maps were generated for $\mathrm{Cr}, \mathrm{Co}, \mathrm{Ni}$ and the zonality index using IDS (Inverse Distance Squared) by Rock Works software package.

The C-A log-log plots were generated for $\mathrm{Cr}, \mathrm{Ni}, \mathrm{Co}$ and zonality index as depicted in Fig 3. For application of the C-A fractal model, the calculated values in cells were sorted based on decreasing values and cumulative areas were calculated for grades corresponding to those areas.

According to the log-log plots, four geochemical populations were distinguished for $\mathrm{Cr}, \mathrm{Co}, \mathrm{Ni}$ and zonality index as illustrated in Fig 4. First threshold value for $\mathrm{Cr}$ is $141 \mathrm{ppm}$ and its enriched part commences from $1496 \mathrm{ppm}$ which is located in the SW and western parts of the area.

The $\mathrm{Cr}$ values lower than $141 \mathrm{ppm}$ can be defined as the background and the second population is between $141 \mathrm{ppm}$ and $512 \mathrm{ppm}$ that relates to weak anomalies. The $\mathrm{Cr}$ values between $512 \mathrm{ppm}$ and $1496 \mathrm{ppm}$ indicate the main anomalies. $\mathrm{Co}$ and $\mathrm{Ni}$ anomalous threshold is $17 \mathrm{ppm}$ and $77 \mathrm{ppm}$ respectively however; the values higher than $54 \mathrm{ppm}$ for Co and $501 \mathrm{ppm}$ for Ni demonstrate enrichment parts of the elements which are situated in the northern, central and western parts of the area (Fig. 4). 

in the Parang 1:100000 Sheet, Iran

Table 1. Statistical parameters for $\mathrm{Cr}, \mathrm{Co}$ and $\mathrm{Ni}$

\begin{tabular}{|c|c|c|c|c|c|c|}
\hline Statistical & Mean & Standard Deviation & Variance & Median & Skewness & Kortosis \\
\hline $\mathrm{Cr}$ & 379 & 286.40 & 82027 & 312 & 3.53272 & 23.35886 \\
\hline $\mathrm{Co}$ & 27.73 & 12.93 & 167.211 & 24 & 1.073 & 0.77643 \\
\hline $\mathrm{Ni}$ & 267 & 200.35 & 40140 & 208 & 1.184 & 0.90321 \\
\hline
\end{tabular}
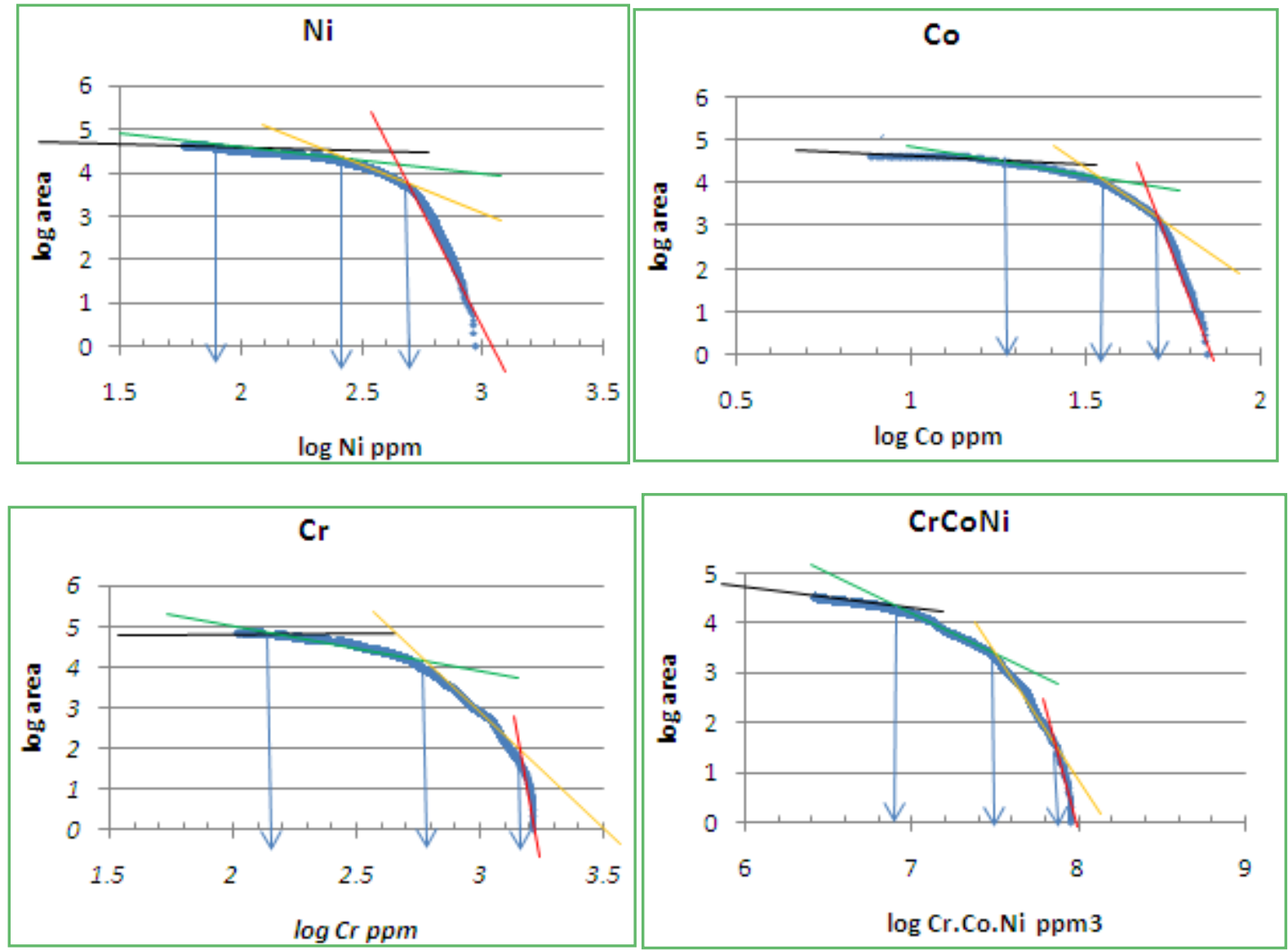

Figure 3. C-A Log-log plots for $\mathrm{Cr}, \mathrm{Co}, \mathrm{Ni}$ and zonality index
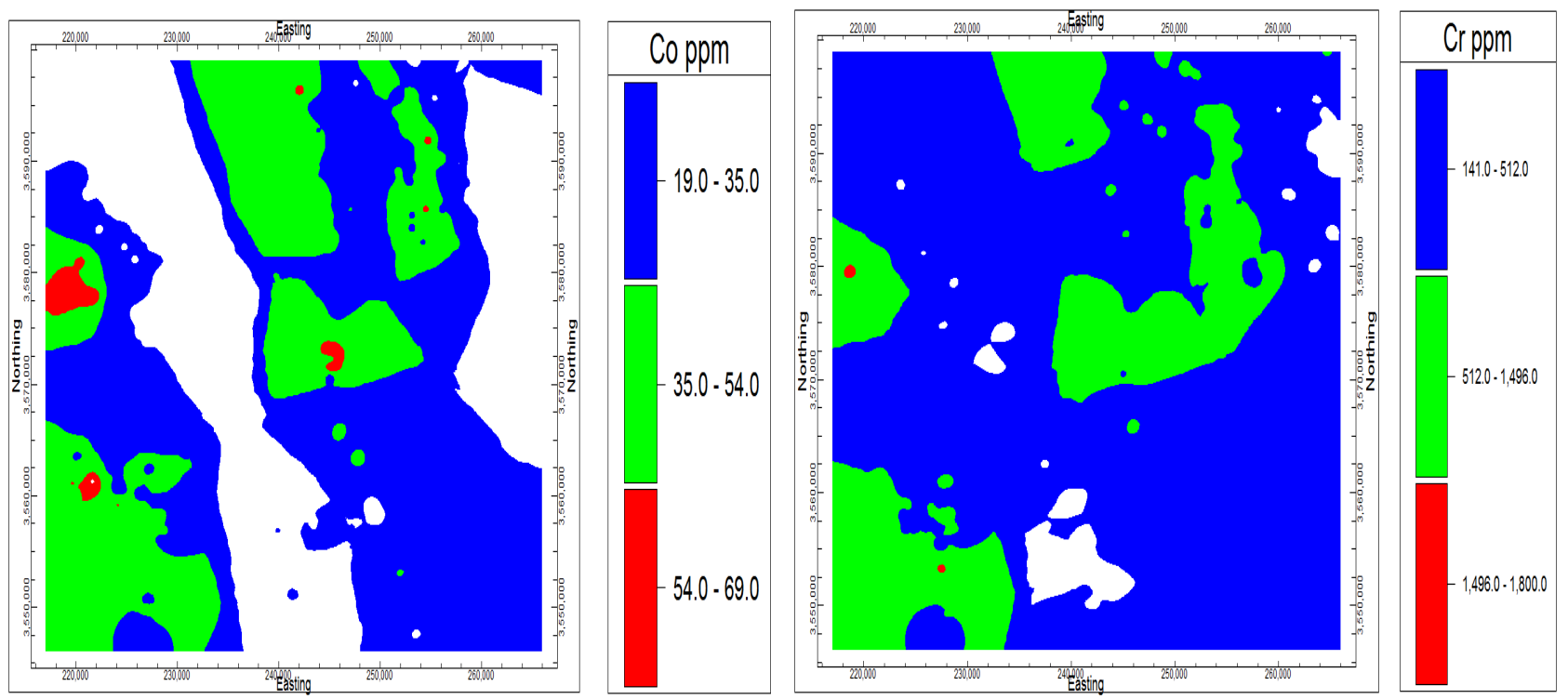

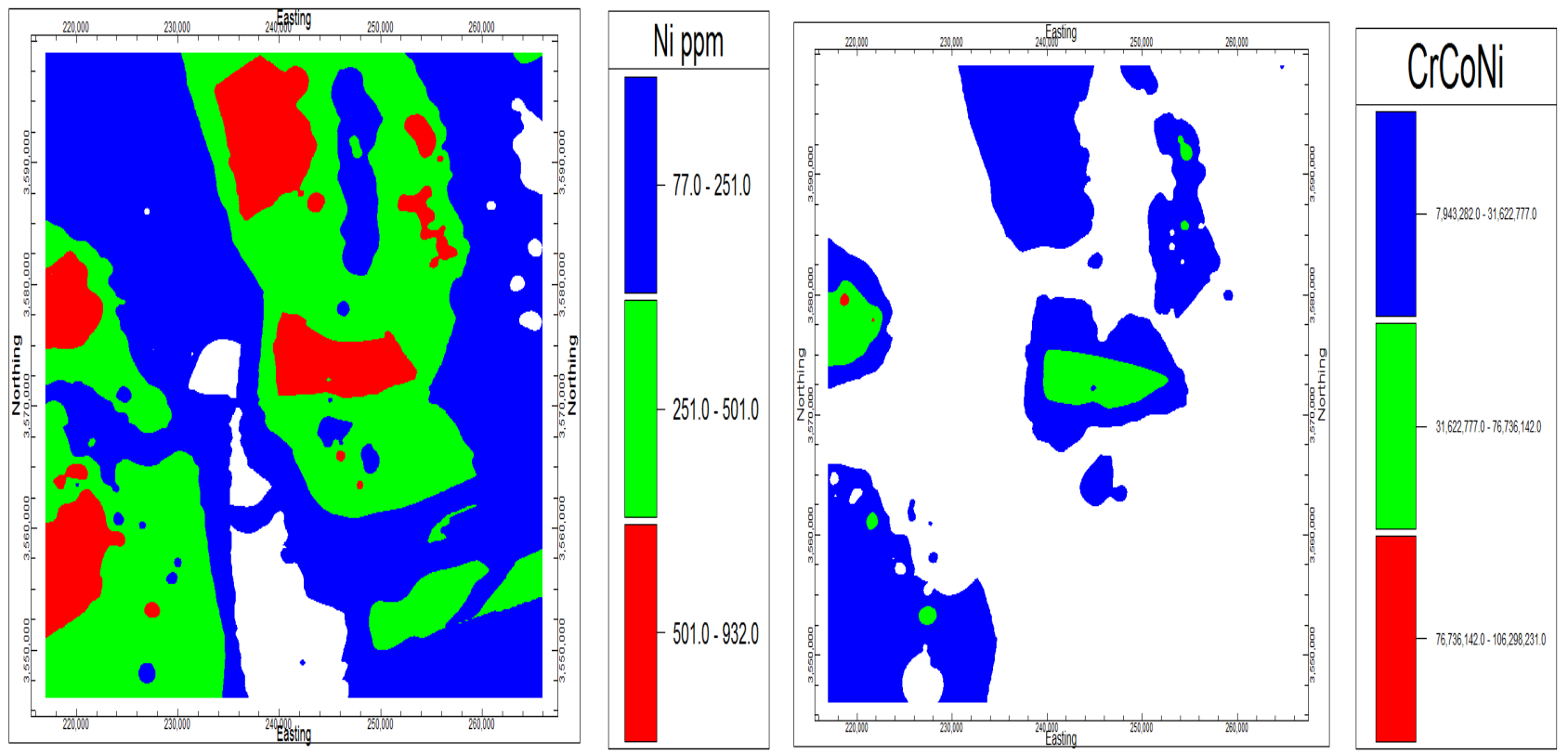

Figure 4. Geochemical anomaly maps of $\mathrm{Cr}, \mathrm{Co}, \mathrm{Ni}$ and multiplied halos of $\mathrm{Cr}$.Co.Ni

The C-A fractal model was utilized for zonality index to show different geochemical populations. The first event for the zonality index occurs at values below 7,943,282 $\mathrm{ppm}^{3}$. The high intensive anomaly for zonality index happened with values higher than $76,736,142 \mathrm{ppm}^{3}$. The high intensity anomalous parts of the zonality index are located in the western and SW parts of the area as well as the high intensive anomalies for $\mathrm{Cr}$ (Fig. 4).

\section{Correlation between Geological Particulars and Multifractal Modeling}

For validation of the resulted chromite prospects, correlation between geological and zonality index models was carried out using the log-ratio matrix. Carranza has proposed this matrix to additional investigation of spatial correlations between two different binary models.

The results obtained by the $\mathrm{C}-\mathrm{A}$ fractal modeling were simplified into tow binary geochemical maps including anomaly and background. Each binary geochemical background anomaly map is crossed with certain part of geological map that ore deposits could be occurrence there. To apply this intersection operation between two binary maps, four overlap conditions happen where the intersection area is calculated for measuring performance of binary geochemical anomaly mapping. Two errors may happen namely; type 1 error (T1E) including the ability of the analysis to background zones and type 2 error (T2E) relates to the ability of the analysis to anomaly zones which lower values of T2E is more important than lower values of T1E. Moreover, high values of overall accuracy (OA) show strong correlation (Table 2).
Table 2. Log ratio matrix for comparing correlation of geochemical modeling results with geological model. A, B, C, and D represent numbers of pixel in overlap between the binary geological model and the binary results of geochemical model (Carranza 2011).

\begin{tabular}{|c|c|c|c|}
\hline \multicolumn{2}{|c|}{} & \multicolumn{2}{c|}{ Geological model } \\
\cline { 3 - 4 } & Inside & Outside \\
\hline \multirow{3}{*}{$\begin{array}{c}\text { Geochemical } \\
\text { model }\end{array}$} & Inside & $\begin{array}{c}\text { True positive } \\
\text { A }\end{array}$ & $\begin{array}{c}\text { True negative } \\
\text { B }\end{array}$ \\
\cline { 2 - 4 } & \multirow{2}{*}{ Outside } & $\begin{array}{c}\text { False positive } \\
\text { C }\end{array}$ & $\begin{array}{c}\text { False negative } \\
\text { D }\end{array}$ \\
\hline \multirow{2}{*}{} & & \multicolumn{2}{|c|}{ T1E C/(A+C) T2E B/(B+D) } \\
\cline { 3 - 4 } & \multicolumn{2}{|c|}{$\begin{array}{c}\text { Overall accuracy } \\
(\mathrm{A}+\mathrm{D}) /(\mathrm{A}+\mathrm{B}+\mathrm{C}+\mathrm{D})\end{array}$} \\
\hline
\end{tabular}

Table 3. Log ratio matrix for comparing correlation of high anomaly of $\mathrm{Cr}$ and multiplied halos with geological model

\begin{tabular}{|c|c|c|c|}
\hline & & \multicolumn{2}{|c|}{ Geological model } \\
\hline & & inside & Outside \\
\hline \multirow{2}{*}{$\begin{array}{l}\text { High anomaly } \\
\text { of } \mathrm{Cr}\end{array}$} & Inside & 4 & 5 \\
\hline & Outside & 6295 & 58564 \\
\hline & & \multicolumn{2}{|c|}{$\begin{array}{c}\text { T1E } 0.999365 \text { T2E } \\
8.53694 \mathrm{E}-05 \\
\end{array}$} \\
\hline & & \multicolumn{2}{|c|}{ Geological model } \\
\hline & & inside & Outside \\
\hline \multirow{2}{*}{$\begin{array}{c}\text { High anomaly } \\
\text { of multiplied } \\
\text { halos of } \\
\text { Cr.Co.Ni }\end{array}$} & Inside & 6 & 14 \\
\hline & Outside & 6293 & 58555 \\
\hline & & \multicolumn{2}{|c|}{$\begin{array}{c}\text { T1E } 0.999047 \text { T2E } \\
0.000239091\end{array}$} \\
\hline & & \multicolumn{2}{|c|}{ Overall accuracy 0.902772} \\
\hline
\end{tabular}

Different anomalies of $\mathrm{Cr}$ and the zonality index were appended into geological map and correlation between these 
anomalies and geological ophiolites sequences were distinguished by using log-ratio matrix. As mentioned above, numbers of cells in overlaps between binary geological model and different parts of the geochemical maps were calculated. Based on the log-ratio matrix, high intensive anomalies defined by means of C-A multifractal modeling for $\mathrm{Cr}$ and multiplied halos shows good association with ophiolite sequences and OA for these models is 0.81 (Table $3)$. However, main anomalies defined by means of C-A multifractal modeling for multiplied halos are lower than multifractal $\mathrm{Cr}$ modeling and show more correlation (Table 4). Furthermore, comparing of the results of weak anomaly for $\mathrm{Cr}$ and zonality index obtained by the $\mathrm{C}$-A fractal model reveals that $\mathrm{OA}$ for zonality index is higher than the main $\mathrm{Cr}$ anomalies (Table 5).

Table 4. Log ratio matrix for comparing correlation of main anomaly of $\mathrm{Cr}$ and multiplied halos with geological model

\begin{tabular}{|c|c|c|c|}
\hline & & \multicolumn{2}{|c|}{ Geological model } \\
\hline & & inside & Outside \\
\hline \multirow{2}{*}{$\begin{array}{l}\text { Main anomaly } \\
\text { of } \mathrm{Cr}\end{array}$} & Inside & 1023 & 7107 \\
\hline & Outside & 5276 & 51462 \\
\hline & & \multicolumn{2}{|c|}{ T1E 0.7386 T2E 0.1381} \\
\hline & & \multicolumn{2}{|c|}{ Overall accuracy 0.809105} \\
\hline & & \multicolumn{2}{|c|}{ Geological model } \\
\hline & & Inside & Outside \\
\hline \multirow{2}{*}{$\begin{array}{c}\text { Main anomaly } \\
\text { of multiplied } \\
\text { halos of } \\
\text { Cr.Co.Ni }\end{array}$} & Inside & 217 & 1861 \\
\hline & Outside & 6082 & 56708 \\
\hline & & \multicolumn{2}{|c|}{ T1E 0.9656 T2E 0.0318} \\
\hline & & \multicolumn{2}{|c|}{ Overall accuracy 0.8776} \\
\hline
\end{tabular}

Table 5. Log ratio matrix for comparing correlation of weak anomaly of $\mathrm{Cr}$ and multiplied halos with geological model

\begin{tabular}{|c|c|c|c|}
\hline & & \multicolumn{2}{|c|}{ Geological model } \\
\hline & & Inside & Outside \\
\hline \multirow{2}{*}{$\begin{array}{c}\text { Weak anomaly } \\
\text { of } \mathrm{Cr}\end{array}$} & Inside & 6219 & 41301 \\
\hline & Outside & 80 & 17269 \\
\hline & & \multicolumn{2}{|c|}{ T1E 0.127 T2E 0.705} \\
\hline & & \multicolumn{2}{|c|}{ Overall accuracy 0.3621} \\
\hline & & \multicolumn{2}{|c|}{ Geological model } \\
\hline & & Inside & Outside \\
\hline \multirow{2}{*}{$\begin{array}{c}\text { Weak anomaly } \\
\text { of multiplied } \\
\text { halos of } \\
\text { Cr.Co.Ni }\end{array}$} & Inside & 2132 & 14380 \\
\hline & Outside & 4167 & 44189 \\
\hline & & \multicolumn{2}{|c|}{ T1E 0.6616 T2E 0.2455} \\
\hline & & \multicolumn{2}{|c|}{ Overall accuracy 0.7141} \\
\hline
\end{tabular}

\section{Conclusions}

Results obtained by this study show that the combination of zonality index and the $\mathrm{C}-\mathrm{A}$ fractal modeling is an applicable tool to prospect ore deposits. Elemental distribution of $\mathrm{Cr}, \mathrm{Co}$ and $\mathrm{Ni}$ shows that their enrichment is located in the western part of the area. Multiplied values of $\mathrm{Cr}, \mathrm{Co}$ and $\mathrm{Ni}$ as a zonality index were applied for demonstration of the new chromite prospects. Distribution of the zonality index indicates an enriched zone in the western and central parts of the area which are introduced as a suitable region for detailed exploration. The obtained results via the $\mathrm{C}$-A fractal modeling for $\mathrm{Cr}$ has the good association with multiplied halos of Cr.Co.Ni model but the area is prospected for $\mathrm{Cr}$ mineralization based on the zonality index modeling which has more agreement with geological evidence. Moreover, due to log-ratio matrix, multiplied halos modeling has better concord with geological model which shows advantage exploration index versus $\mathrm{Cr}$ modeling. The overall accuracy of the weak anomaly of $\mathrm{Cr}$ and weak anomalies of multiplied of $\mathrm{Cr}$.Co.Ni are equal to 0.3621 and 0.7141 respectively. Furthermore, OAs are 0.8091 and 0.8776 for the main mineralization of $\mathrm{Cr}$ and the zonality index. Finally, in the high intensive anomalies, values of overall accuracy are approximately equal so the results of two models in the enriched zones are equal.

\section{REFERENCES}

[1] Goldberg, I.S., Abramson, G.Ya., Los, V.L., 2003. Depletion and enrichment of primary halos: their importance in the genesis and exploration for mineral deposits. Geochem . Explore. Environ. Anal. 3,pp 281-293.

[2] Govett, G.J.S. (Ed.), 1983. Rock Geochemistry in Mineral Exploration. Handbook of Exploration Geochemistry, 3. Elsevier, Amsterdam. 461 pp.

[3] Safronov, N.I., 1936. Dispersion halos of ore deposits and their use in exploration. Probl. Sov. Geol. 4,pp 41-53.

[4] Carranza, E.J.M, 2012. Primary geochemical characteristics of mineral deposits - Implications for exploration, Ore Geology Reviews 45,pp 1-4.

[5] Bierlein, F.P., Fuller, T., Stüwe, K., Arne, D.C., Keays, R.R., 1998. Wallrock alteration associated with turbidite-hosted gold deposits. Examples from the Palaeozoic Lachlan Fold Belt in central Victoria, Australia. Ore Geol. Rev. 13,pp 345-380.

[6] Hannington, M.D., Santaguida, F., Kjarsgaard, I.M., Cathles, L.M., 2003. Regional-scale hydrothermal alteration in the Central Blake River Group, western Abitibi subprovince, Canada: implications for VMS prospectivity. Miner. Deposita 38,pp 393-422.

[7] Lovering, T.S., 1949. Rock Alteration as a Guide to Ore East Tintic District, Utah. Economic Geology Monograph 1. Economic Geology Publishing Co., Urbana, Illinois. 64 pp. 
[8] Carranza, E.J.M, 2012. Primary geochemical characteristics of mineral deposits - Implications for exploration, Ore Geology Reviews 45,pp 1-4.

[9] Plant j. A., Hale M. and Ridgeway j.1989.regional geochemistry based on stream sediment sampling. Exploration 87 proceeding AEG symp. Toronto, edited by G. D garland Ontario geological survey, special volume No.3 pp. 384-404

[10] Beus, A.A., Grigorian, S.V., 1977. Geochemical Exploration Methods for Mineral Deposits. Applied Publishing Ltd., Wilmette, Illinois.

[11] Ivanov, V.V. Meituv,G.M.,1972. Geological and Geochemical Investigations of Ore Provinces. Nedra, Moscow152pp. ( In Russian).

[12] Shcheglov, A.D., 1979. Fundamentals of Metallogenic Analysis. Mir Publishers, Moscow 335pp. (Trans .from Russian by V. Shiffer ).

[13] Ziaii, M., caranza, E.J.M, ziaii, M., 2011. Application of geochemical zonality coefficientsin mineral prospectivity mapping, Computers \&Geosciences 37, pp 1935-1945.

[14] Mandelbrot, B.B., The Fractal Geometry of Nature, W. H. Freeman, San Fransisco, (1983), p. 468.

[15] Afzal, P., Khakzad, A., Moarefvand, P., Rashidnejad Omran, N., Esfan-diari, B., Fadakar Alghalandis, Y. 2010, Journal of Geochemical Exploration 104, pp. 34-46.

[16] Afzal, P. Hashemi, M. Ras, I. Noghreia, M. Tehrani and Vosoughi Abedini, M, 2010, Geochemical anomaly separation by Concentration-Area fractal model in Bardaskan area, NE Iran. Journal of Mining and Metallurgy, 46 A (1) 10

[17] Agterberg, F.P., Cheng, Q., Brown, A., Good, D., Computers \& Geo-sciences 22 (1996), pp. 497-507.

[18] Cheng, Q, Agterberg, F. P., Ballan-tyne, S. B., (1994). Journal of Geochemical Exploration 51, pp. 109-130.

[19] Goncalves, M.A., Mathematical Geology 33 (2001), pp. 41-61.

[20] Halsey, T.C., Jensen, M.H., Kada-noff, L.P., Procaccia, I., Shraiman, B.I., Physical Review A 33 (1986), pp. 1141-1151.

[21] Meng, X, Zhao, P., Chinese Journal of Geosciences, 2 (1991), pp. 207-211.

[22] Sim, B.L., Agterberg, F.P., Beaudry, C., Computers \& Geosciences. 25 (1999), pp. 1023-1041.

[23] Turcotte, D.L., Economic Geology, 18 (1986), pp. $1525-1532$.

[24] Wei, Sh., Pengda, Zh., Computers \& Geosciences 28 (2002), pp. 369-376.

[25] Tirrul, R., Bell, 1. R., Griffis, J. R. \& Camp, V. E., 1983. The sistan suture zone of Eastern Iran. G. S. A. Bulletin 94,pp 134
$-150$.

[26] Lensch, G., Davoudzadeh, M., 1982. Ophiolites in Iran. Neues Jb. Geol. Paläontol. Monatsh. 5, pp 306-320.

[27] Stöcklin, J., 1977. Structural correlation of the Alpine range between Iran and Central Asia. Mémoire Hors-Série No.8 de la Société Géologique de la France, 8, pp. 333-353.

[28] Ahmadipour, H., Sabzehei, M., Whitechurch, H., Rastad, E., Emami, M.H., 2003. Soghan complex as an evidence for paleospreading center and mantle diapirism in Sanadaj-Sirjan zone (south-east Iran). J. Islam. Repub. Iran. 14, 157-172.

[29] Alavi-Tehrani, N., 1977. Geology and Petrography in the Ophiolitic Range of Sabzevar (Khorasan, Iran). Geological Survey of Iran. Report 43.

[30] Arvin, M., Robinson, P.T., 1994. The petrogenesis and tectonic setting of lavas from the Baft ophiolitic mélange, southwest of Kerman, Iran. Can. J. Earth Sci. 31, 824-834.

[31] Davoudzadeh, M., 1972. Geology and Petrography of the Area North of Nain, Central Iran. Geological Survey of Iran. Report 14.

[32] Delaloye, M., Desmons, J., 1980. Ophiolites and mélange terranes in Iran: a geochronological study and its paleotectonic implication. Tectonophysics $68,83-111$.

[33] Desmons, J., Beccaluva, L., 1983. Mid-ocean ridge and island-arc affinities in ophiolites from Iran: palaeographic implications. Chem. Geol. 39, 39-63.

[34] Gansser, A., 1960. Ausseralpine Ophiolithprobleme. Eclogae Geol. Helv. 52 (2), 659-680.

[35] Ghasemi, H., Juteau, T., Bellon, H., Sabzehei, M., Whitechurch, H., Ricou, L.-E.,2002. The mafi-cultramafic complex of Sikhuran (central Iran): a polygenetic ophiolite suite. C.R. Geosci. 334, 431-438

[36] Kananian, A., Juteau, T., Bellon, H., Darvishzadeh, A., Sabzehi, M., Whitechurch, H., Ricou, L.-E., 2001. The ophiolite massif of Kahnuj (western Makran, southern Iran): new geological and geochronological data. C.R. Acad. Sci. Paris, Sci. Terre Planets 332, 543-552.

[37] Lensch, G., Mihm, A., Alavi-Tehrani, N., 1977. Petrography and geology of the ophiolite belt of Sabzevar, Khorassan (Iran). Neues Jb. Mineralog. Abh. 131, 156-178.

[38] McCall, G.J.H., 1997. The geotectonic history of the Makran and adjacent areas of southern Iran. J. Asian Earth Sci. 15, 517-531.

[39] Yigit, O., 2008, Mineral deposits of Turkey in relation to Tethyan metallogeny-Implications for future mineral exploration: Economic Geology, v. 104, no. 1, p. 19-51.

[40] Carranza E.J.M. 2011: Analysis and mapping of geochemical anomalies using logratio-transformed stream sediment data with censored values. J. Geochem. Exploration 110, $167-185$. 